\title{
Capacity Building of Village-owned Enterprises in Strengthening Village Economy
}

\author{
Moh Said*, Erlita Cahyasari, Suhartono Winoto \\ Public Administration Department \\ Faculty of Administrative Science Universitas Brawijaya \\ Malang, Indonesia \\ *mohsaid_fia@ub.ac.id
}

\begin{abstract}
This study aimed to develop the capacity and institution of Village-owned Enterprises as a driving force for the village economy. The existence of Village-owned Enterprises as a pillar of economic activity in the village has a function as a social institution as well as a commercial institution. This study used system thinking approach with the system archetype method. The location of the Village-owned Enterprises capacity building research was in Batu City. The results showed that the process of building the capacity of Village-owned Enterprises in Batu City referred to the concept of capacity building from Grindle which was carried out at three levels, namely system level, organizational level, and individual level. Based on the Villageowned Enterprises capacity building model produced, there were several factors, namely leadership factor, role factor for village government, managerial and organizational factor as well as technological factor that can leverage Village-owned Enterprises capacity building. Village-owned Enterprises capacity building has been carried out, even business development to technology utilization has been implemented. However, the management structure of the Village-owned Enterprises in Batu City has not been completely separated from the village government. Through the Village-owned Enterprises capacity building and institutional governance model, it can support efforts to embody the concept of building a regional economy starting from the village economy.
\end{abstract}

Keywords—capacity building, village economy

\section{INTRODUCTION}

Village development management comes to a new phase with the enactment of Law Number 6 of 2014 concerning Village. The village government has broader authority to be creative in managing its potential. The willingness to improve welfare through strengthening the village economy is becoming stronger with the existence of regulations on VillageOwned Enterprises. The establishment of this business entity is regulated in the Regulation of the Minister of Village, Development of Disadvantaged Regions and Transmigration Number 4 of 2015 concerning the Establishment, Administration and Management, and Termination of VillageOwned Enterprises. Economic development is believed to be the foundation for accelerating rural development. Village economic institutions that are burdened with the role of being the motor of the village economy are village-owned enterprises.

Village-owned enterprises are village business institutions managed by the community and village administration in an effort to strengthen the village economy. Its establishment is based on the needs and potential of the village. It is expected that the existence of the Village-owned Enterprises will become a pillar of economic activity in the village that functions as a social institution as well as a commercial institution. As a social institution, it must have aligned values, namely for the benefit of the community through its contribution in the provision of social services. Meanwhile, as a commercial institution, it aims to seek profit through offering local resources to the market, which can provide welfare for rural communities [1]. In order for the village community to develop its potential and benefit, it requires equal distribution of resources [2].

Ideally, the Village-owned Enterprise is expected to be the driving force for village scale local businesses which will then leverage the success and acceleration of development in the village. However, at a relatively new age, its existence has an optimal effect on the economic growth of rural communities. Many Village-owned Enterprises are facing problems with their institutional structure and capacity. For the sake of realizing the functioning of the Village-owned Enterprises existence, efforts are needed to strengthen its capacity and organize its institutions. The Village-owned Enterprises capacity building process must start internally. It should initiate plans on the development of existing capacity. An organization that is internally healthy is possible to be capable of solving its external environment. Village-owned Enterprises must conduct a capacity analysis first, and then find a solution to improve its performance. Structural and institutional arrangements are expected to increase the efficiency, effectiveness, and responsiveness of the Village-owned Enterprises [3].

One of the autonomous regions that has great potential in developing Village-owned Enterprises is Batu City. This city has a rapid development based on a creative economy. The uniqueness of this city is its characteristic which is a combination of urban and rural which seems balanced. This 
means that there is great potential for the rural economy, if it is supported by a strong Village-Owned Enterprise, the growth of the rural economy will become a pillar of economic progress in Batu City. Strengthening the capacity of Village-owned Enterprises must be carried out continuously in urban and rural areas. Capacity building touches three dimensions, starting from the system level in relation to regulations and values being developed. Then, the organizational level includes organizational structure, decision-making processes, work procedures and mechanisms, arrangement of facilities and infrastructure, relations and networks. Then, what is no less important is the individual level in which it is as the activator of the Village-owned Enterprise organizational system. Strengthening individual capacity includes skills, knowledge, behavior, and work motivation in organizations

It requires deep exploration of the potential, the capacity of human resources in the village, and the orientation and capacity of the village community in developing their potential and opportunities. The results of the exploration are used as materials for structuring the institution and capacity building of the Village-owned Enterprises so that it meets the criteria of efficiency, effectiveness, and responsiveness in realizing optimal performance. Exploitation to uncover the problems faced by Village-owned Enterprises in Batu City is done from the understanding and knowledge of village officials and Village-owned Enterprises managers on the functions and roles of Village-owned Enterprises. Then the management capacity needs of Village-owned Enterprises to manage village potential which can be developed in line with regional economic growth. In addition, it is also important to understand how the business process orientation will be expressed in Village-owned Enterprises structures and institutions that have the strength and flexibility in adapting to the external environment.

Through institutional structuring and capacity strengthening, it can make it easy for village governments and Village-owned Enterprises managers to finalize potential and prioritize program activities that have a positive effect on village economic progress and contribute positively to regional economic growth. A reliable institutional structure according to the potential and challenges of progress can be a golden way for the development of a Village-owned Enterprise. Capable institutions and capacities balanced with mapping of village economic potential can avoid bias and ineffectiveness of business unit development. Mapping the economic potential of the village can be done based on the results of reading the natural economic activities of the village community which have proven to be able to survive and produce in a long term. Then, businesses related to meeting the basic needs of rural communities as well a reading potential opportunities in line with the dynamics of businesses are managed by Villageowned Enterprises.

\section{THEORETICAL REVIEW}

\section{A. Village-Owned Enterprises}

An understanding of Village-Owned Enterprises (BUM Desa) can refer to the definition of the laws and regulations that govern it. According to Article 1 paragraph (6) of the Minister of Home Affairs Regulation Number 39 of 2010 concerning Village-Owned Enterprises, it is explained that Village-owned Enterprises is a village business established/formed by the village government whose capital ownership and management are carried out by the village government and the community. Furthermore, Village-owned Enterprises according to Article 78 of Government Regulation Number 72 of 2005 Regarding Villages states that in order to increase community and village income, the village government can establish a Village-Owned Enterprise which is stipulated by village regulations based on the prevailing laws and regulations. Another definition from the Development System Dynamics Study Center [4], which states that Villageowned Enterprises is a village business institution managed by the community and village government in an effort to strengthen the village economy and is formed based on the needs and potential of the village.

The establishment and management of Village-Owned Enterprises (BUM Desa) is a manifestation of the management of the village's productive economy, which is carried out in a cooperative, participatory, emancipatory, transparent, accountable, and sustainable way. The main objectives of establishing a Village-owned Enterprise are: a) Increasing the village economy; b) Increasing the local own-source revenue; c) Increasing the processing of village potential according to community needs; and d) Becoming the backbone of rural economic growth and equity. In an effort to establish Villageowned Enterprises, it is necessary to understand the suitability between the form of the organization, the pattern of the implementation, and the type of business that will be developed with the capacity and potential of each village and the characteristics of the community.

\section{B. Village-owned Enterprises Capacity Building and Institutional Governance}

The concept of capacity building implies an initiative in developing existing capacity. It also means a creative process to build unseen capacity. The objective is to improve performance. Grindle [3] explains that capacity building is an effort to develop various strategies for efficiency, effectiveness, and responsiveness. Three levels in capacity building that must be carried out effectively and sustainably, namely:

- system level, such as a framework that deals with the regulation, policy, and basic conditions that support the achievement of certain policy objectivity;

- institutional level or the whole unit, for example, the structure of organizations, decision-making processes within organizations, work procedures and mechanisms, 
arrangement of facilities and infrastructure, organizational relations and networks;

- individual level, for example, individual skills, knowledge, behavior, and motivation of individuals in organizations.

Capacity building is influenced by several main factors, namely a) joint commitment of all actors involved in an organization, b) conducive leadership, which is one of the fundamental things in influencing the initiation and success of capacity building, both personal and institutional in an organization, c) regulatory reform, for the availability of good and factual legislation in order to reduce formal legal issues to capacity building, d) institutional reform which essentially points to the development of a climate and culture that is conducive to the conduct of organizational affairs towards the realization of goals, and e) strengths and weaknesses recognition, namely the identification of the capacity owned as a starting point for development.

Strengthening Village-owned Enterprises is influenced by many factors in various dimensions of life in the village. The results of research done by Rahmat [5] which are also corroborated by the research conducted by Zandri et al. [6] explain that Village-owned Enterprises institutional development must pay attention on several variables, namely: leadership, doctrine, program, resources, internal structure, enabling linkages. These enabling linkages include: functional, normative, and diffuse linkages. Murwadji et al. [7] added that the success of Village-owned Enterprises is related to linkage programs and capital. There is a common thread between the 2014 and 2017 research that it is important to have a linkage program for Village-owned Enterprises. Then, Fathoni and Susilowati [8] added that the success of Village-owned Enterprises is influenced by resources, managerial, technological mastery, market competition, and the economic and social conditions of the village.

Apart from several factors discussed by some of these previous studies, it was also found that Village-owned Enterprises cannot be separated from the role of the village government. The role of the village government is as a driving force for the professionalism of Village-owned Enterprises managers [9]. Meanwhile, the profit obtained by the village is the sharing of business results which helps in increasing the local own-source revenue. Then, the results of Imamuddin's research [10] explain that community participation in the management of Village-owned Enterprises can be a supporting and inhibiting factor for Village-owned Enterprises. If the community actively participates in iy, it becomes a supporting factor for its success, but if the participation is low, it will become an inhibiting factor.

\section{RESEARCH METHODS}

This study uses system thinking approach, with the system archetype method. The use of the system archetype as a method in evaluation research is believed to be able to assist in conducting in-depth research on complex phenomena. Through the use of a model or standard framework for existing system behavior, it makes it easier to recognize the patterns and behavior of the system under study. This research requires indepth information in order to obtain a complex picture for modeling a reality in the field. As explained by Guijt and Roche [11], complex research requires a complex perspective and plural way of thinking. This study describes the elements of the phenomenon studied [12], namely the causal relation between elements in strengthening the capacity and institutional arrangement of Village-owned Enterprises in Batu City.

\section{DISCUSSION}

The capacity of Village-owned Enterprises in Batu City, according to research data, shows that it still needs improvement. Currently, the management of capacity building or managerial capacity is still running existing businesses with limitations. However, there is a side of extraordinary enthusiasm shown by the management of Village-owned Enterprises. The motivation to develop Village-owned Enterprises to be better is sparked by the aspiration to change existing conditions for the betterment. Especially changing the economic conditions of the village to be optimal and contributing maximally to the improvement of the welfare of local communities.

Managerial and organizational performance refers to the opinion of Grindle [3] that capacity building can be carried out by using several strategies which include the dimensions of human resources, organizational, and system or institutional improvement. Managing an organization requires both human resources and other organizational resources, including networking. The process of building the capacity of the Village-owned Enterprises in Batu City refers to the concept of capacity building from Grindle [3] which is carried out at three levels but must be carried out effectively and sustainably, namely:

- System level, the existence of Village-owned Enterprises as an economic institution at the village level is extremely strong because its foundation is in Law Number 6 of 2014 which provides authority to the village government to form economic institutions that can manage the economic potential of the village in order to improve the economic welfare of rural communities. Then, the provisions in the law are derived from government regulations and ministerial regulations. It has even been followed by a village regulation as a stipulation on the establishment of Village-owned Enterprises;

- Organizational level, namely how the framework is built within the whole unit, both organizational structure, decision-making processes, procedures and work mechanisms, arrangement of facilities and infrastructure, work relations patterns, and organizational networking. Village-owned enterprises in Batu City, even though it is simple, it has an 
organizational structure, work procedure, and a pattern of utilizing its authority and accountability;

- Individual level, the village government facilitates Village-owned Enterprises administrators to continue to learn and increase their capacity as individuals and as work teams. In addition to skills and knowledge, there are things that are also essential for the management to understand correctly, namely understanding the social and cultural values of society as a basis for behavior, job grouping, and motivation in carrying out tasks in the organization.

Capacity building is influenced by the joint commitment of all actors, the village government is committed to including capital from village funds as stimulation for the establishment of Village-owned Enterprises. As long as the institution is still unable to develop itself independently, the village government will act as a supervisor. The leadership of the village head is quite influential on the motivation of the Village-owned Enterprises managers. Conducive leadership is one that is fundamental in influencing the initiation and success of Village-owned Enterprises management. The availability of legislation is a supporting factor that can reduce formal legal issues to the management and development of Village-owned Enterprises.

Other factors that influence the capacity building of Village-owned Enterprises are participation, access to information, and accountability [13]. Participation is understood as a condition for the involvement of all related actors in the development of Village-owned Enterprises. Then, accountability is as a means of controlling program implementation so that it can achieve the desired goals. These three factors are most closely related to leadership, which function as driving forces, directors and controllers at each stage of the process of implementing activities in Villageowned Enterprises.

\section{A. Institutional Strengthening}

Institutional strengthening must start from the initial process, namely determining strategic policies which then direct the strategic plans for each element of the organization. In the planning phase, Village-owned Enterprises as a dynamic organization must carry out strategic planning, medium-term planning, and even long-term planning. Another thing that is important to understand is the quality of the institution, managerial skills including leadership style, and accountability systems and organizational culture. As explained by Withtaker [14] that strategic planning includes at least the design of a functional organizational structure in order to achieve the goals set. Institutional reform must be based on the need for the development of business fields in line with the objectives that have been formulated. The dimensions of institutional strengthening include: (1) policy development, (2) organizational network development, (3) management development, (4) public accountability system development, and (5) organizational culture development.

\section{B. Human Resources Strengthening}

The availability of human resources at Village-owned Enterprises in Batu City is relatively inadequate in terms of quality. However, in terms of quantity, each village has enough generation that can be prepared to manage Village-owned Enterprises. This does not mean that the village community is not qualified, but because the existence of Village-owned Enterprises is relatively new, adequate adjustment and support is needed so that human resources in the village can accelerate in building Village-owned Enterprises with community needs and market developments. A human resource development framework must exist, so that the capacity building process remains in the designated space. For example, strategic areas in the strategic plan should also determine the type, quantity and quality of human resources needed. Frequently, human resource development is not linked to strategic needs. Human resource development in Village-owned Enterprises should be focused on (1) skill and expertise, (2) insight and knowledge, (3) personality and work motivation, and (4) morale and work ethic.

In order for human resource development to be more on target, capacity building needs to consider 4 (four) basic phases [3]; The first, the design phase which includes the involvement of strategic actors, in this case, ranging from the village government, municipal government, even to the central government, including the share of higher education. Second, the program implementation phase which selects implementers to initiate and implement certain types of activities. Third, the capability acquisition phase, from various activities and trainings that occur as well as informal experiences that can form new skills including improving insights, talents, potential and work ethic. Fourth, the achievement/performance phase, in which it is individual abilities are manifested in the achievement of tasks and final results.

\section{Networking Development}

The development of networking may have a close meaning with building partnership. The point is that two or more parties within a certain period of time achieve mutual benefit with the principle of mutual need and mutual benefit. Although the strategic plan has provided direction for the development of existing human resources and institutions, carrying out these various developments certainly have various limitations. Therefore, there must be a learning process and collaboration between the parties involved or partners. There is freedom to learn or study from each other and share experiences with other organizations, even business competitors. Collaboration highly helps the fast learning process, creates a broader linkage of interests, but still pays attention on the principle of equal rights and obligations.

The institutional arrangement must be carried out completely, because what is designed from the start will affect the future of the organization. There are several things that need to be considered in managing the organization, namely: 
- Operational role; In an increasingly rapid environmental change, in the future, Village-owned Enterprise needs to be designed so that it is able to accommodate heterogeneous and dynamic types of activities, coordinate with various product/service management networks. Village-owned Enterprises must develop core competencies so that it can survive with its advantages.

- Activities and processes flow; organization is seen as the processing of resources provided by suppliers to be transformed into outputs and submitted to costumers. The scope of organizational processes at least includes a variety of functional processes, such as human resources, operations, finance and others whose activities are limited in organizational units. Crossfunctional processes are often expressed in the form of standard operating procedures that apply throughout the organization, such as systems for procurement of goods and services, financial systems and accounting.

- Human Resources; Organizing human resources is grouped into clumps of managerial, professional, and executive jobs. Through human behavior, true excellence can be achieved and can have a future that is harmonious and balanced. Human behavior plays a central role, critical, and has a broad impact in determining the choice of change for success and overcoming the problems faced. Therefore, Villageowned Enterprises must be based on the values that develop in the community.

Thus, managing the Village-owned Enterprises organization requires adaptation to various dynamics, both internal and external to the organization. For this reason, a qualified strategy is needed to enable the organization to adapt perfectly. It is started from the vision, mission and goals of the organization that have been set since the beginning of the organization. Village-owned Enterprises must consider the strength of the external environment and the organization's value system to determine the organizational strategy, management function and the organization that embodies it. Adaptation is done by changing the internal and external organizations. For example adjusting the organizational structure and adopting or acquiring value or resources from outside the organization. Organizational adaptation has a perception of the conditions of its business environment which is used as the basis for determining organizational strategy for performance optimization. Based on the discussion above, the Village-owned Enterprises capacity building model seen from the elements that influence it can be described systemically. Village-owned enterprises capacity building model in Batu City can be seen in Figure 1.

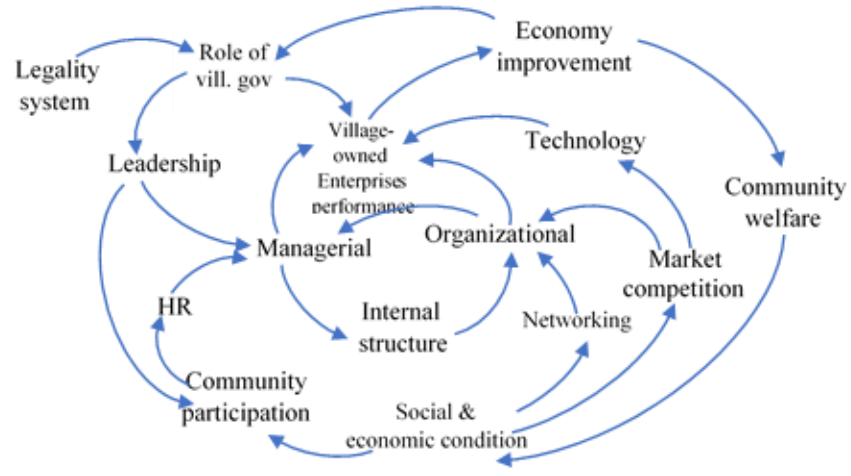

Fig. 1. Village-owned enterprises capacity building model in Batu City (Processed by researchers)

\section{CONCLUSION}

The governance of Village-owned Enterprises in Batu City still needs to find a standard form according to its potential and capacity. Governance includes guidance, operation or implementation, and supervision. These three things are reflected in the organizational structure made by Villageowned Enterprises. Guidance is carried out by the Village Government and the Municipal Government in terms of building strong knowledge and understanding on the basis of the law and the Village-owned Enterprise business legality system including the inclusion of village funds as initial capital for the establishment of Village-owned Enterprises. The operational implementation of Village-owned Enterprises management in Batu City is based on the potential of each village, including the management capacity or human resources. Several Village-owned Enterprises have undergone business development (type of business and scope of business coverage) by building networking with actors outside the village. The use of information technology is one of the main ways to expand the reach of Village-owned Enterprises businesses. The management structure of the Village-owned Enterprises in Batu City has not been completely separated from the village government. However, in this structure, there has been one element that functions as a supervisor. Hence, supervision is no longer fully from the village government. Although in practice, the Village-owned Enterprises operation is still under the influence of the village head's leadership.

Building a regional economy based on a village economy is one of the beliefs of the Mayor of Batu. Therefore, the tourism sector is also built from its base, namely rural areas. Village economy is an economic building that is based on unity and coherence of business by strengthening solidarity. A value that has been and is still deeply rooted in rural community is social solidarity. This value can be adopted into the framework of village economic business management. The Village-owned Enterprises capacity building model and institutional governance to strengthen the economy of rural communities is built by taking into account internal and external factors. Internal factors include organizational strengthening, human 
resource capacity, and networking development. External factors include the clarity of the legality system of the Villageowned Enterprises existence, social and economic conditions, and work networking that can affect the performance of Village-owned Enterprises.

\section{REFERENCES}

[1] D.M. Wibowo, Mendorong Pengelolaan BUMDesa Secara Profesional, $2020 . \quad$ [Online] Retrieved from: https://www.wartaekonomi.co.id/read231487/mendorong-pengelolaanbumdesa-secara-profesional

[2] R. Chambers, PRA (Participatory Rural Appraisal) Memahami Desa Secara Partisipatif. Yogyakarta: Penerbit Kanisuis, 1996.

[3] M.S. Grindle, Getting Good Government Capacity Building in the Public Sectors of Developing Countries. New York: Harvard University Press, 1997.

[4] Pusat Kajian Dinamika Sistem Pembangunan, Buku Panduan Pendirian dan Pengelolaan Badan Usaha Milik Desa. Malang: Departemen Pendidikan Nasional, Fakultas Ekonomi, Universitas Brawijaya, 2007.

[5] A.B.G. Rahmat, "Perencanaan Skenario Badan Usaha Milik Desa (BUMDES) UNTUK Menambah Sumber Pendapatan Desa (Studi di Desa Karangpatihan, Kecamatan Balong, Kabupaten Ponorogo)," Jurnal Administrasi Publik, vol. 2, 2014.

[6] L.P. Zandri, N.D.N. Putri, and R.A. Fahmi, Strategi Pengembangan Badan Usaha Milik Desa (Bumdes) Dharma Utama. Yogyakarta: UII 2018
[7] T. Murwadji, D.S. Rahardjo, and H. Hasna, "BUMDES sebagai badan hukum alternatif dalam pengembangan perkoperasian indonesia," ACTA DIURNAL Jurnal Ilmu Hukum Kenotariatan, vol. 1, pp. 1-18, 2017.

[8] S. Fathoni and I. Susilowati, Penentuan Prioritas Proyek Menggunakan Fuzzy Analytic Network Process (Studi Kasus BUMDes Desa Kemudo Kecamatan Prambanan Kabupaten Klaten). Semarang: Fakultas Ekonomika dan Bisnis, UNDIP, 2017.

[9] D. Purnamasari, "Peran Badan Usaha Milik Desa (BUMDes) dalam Meningkatkan Kesejahteraan Masyarakat Desa (Studi Kasus Desa Minggirsari, Kecamatan Kanigoro, Kabupaten Blitar).” Jurnal Administrasi Publik, vol. 3, pp. 1655-1660, 2015.

[10] I. Imamuddin, Partisipasi masyarakat dalam pengelolaan Badan Usaha Milik Desa (BUMDESa): studi kasus di Desa Payaman Kecamatan Solokuro Kabupaten Lamongan. Surabaya: UIN Sunan Ampel Surabaya, 2018 .

[11] I. Guijt and C. Roche, "Does Impact Evaluation in Development Matter? Well, It Depends What It's for!," European Journal of Development Research, vol. 26, pp. 46-54, 2014.

[12] A.R. Herawati, Sistem Kemitraan Usaha Mikro, Kecil dan Menengah (UMKM) - Usaha Besar Dengan Pemodelan Systems Archetype. Jakarta: Universitas Indonesia, 2011.

[13] T. Yuwono, "Capacity Building in the Local Government: Concept and Analysis", Seminar Internasional Democracy and Local Politics yang Diselenggarakan oleh PSSAT UGM, STPMD "APMD, UAJY, Yogyakarta, 7-8 Januari, 2003.

[14] J.B. Withtaker, The government Performance and Result Act of 1993: A Mandate for Strategic Planning and Performance Measurement. Arlington, Virginia: Educational Services Institut, 1995. 